\title{
„Stabilność sektora finansów publicznych” w warunkach pandemii COVID-19
}

\section{"Stability of the public finance sector" in the COVID-19 pandemic}

Streszczenie. Stan finansów publicznych w Polsce w warunkach pandemii COVID-19 ulega dynamicznym zmianom. Analiza danych statystycznych dotyczących zadłużenia publicznego (jak i jego części składowych), a także związanych ze zobowiązaniami niewymagalnymi pozwala wskazać możliwe obszary zagrożenia stabilności i bezpieczeństwa sektora finansów publicznych. W badaniach wykorzystano przede wszystkim dwie metody badawcze, tzn. metodę dogmatycznoprawną oraz metodę analityczną. Założeniem autora było podkreślenie znaczenia podstaw aksjologicznych prawa finansów publicznych w procesie stanowienia i stosowania tego prawa, ukazanie obowiązujących rozwiązań finansowoprawnych służących kontroli stanu zadłużenia publicznego w Polsce, a także ich istoty dla utrzymania stabilności finansów publicznych. Przeanalizowano w związku z powyższym nie tylko obowiązujący stan prawny, ale także dane dotyczące kwoty państwowego długu publicznego, długu Skarbu Państwa i nie- 
wymagalnych zobowiązań Skarbu Państwa i jednostek sektora finansów publicznych z tytułu udzielonych poręczeń i gwarancji w latach 2016-2020. Ze względu na dostrzeżone różnice za potrzebne uznano również omówienie metodologii liczenia długu publicznego w prawie polskim i unijnym. W tym zakresie można bowiem dostrzec istotne zmiany, zwłaszcza w okresie pandemii COVID-19.

Słowa kluczowe: konstytucyjny limit zadłużenia; państwowy dług publiczny; poręczenia; gwarancje; Skarb Państwa.

\begin{abstract}
The state of public finances in Poland during the COVID-19 pandemic has been changing dynamically. An analysis of statistical data on public debt (and its components), as well as data related to unmatured obligations, allows to indicate possible areas of a threat to the stability and security of the public finance sector. For the purpose of this research two research methods have been mainly used, i.e. the dogmatic and legal method and the analytical method. The Author's intended to emphasize the importance of axiological foundations of the public finance law in a process of establishing and applying this law. He also wanted to present the applicable financial and legal solutions to control a state of public debt in Poland. Author analysed current law, data on the amount of the state public debt, the debt of the State Treasury, as well as unmatured obligations of the State Treasury and public finance sector entities (under sureties and guarantees granted in 2016-2020). Due to the perceived differences, it was also considered necessary to discuss a methodology of calculating public debt in Polish and EU law. This is because in this regard significant changes can be seen, especially during the COVID-19 pandemic.
\end{abstract}

Keywords: constitutional debt limit; public debt; sureties; guarantees; State Treasury; stability of the public finance sector.

\title{
1. Wstęp
}

Zagadnienie wzrastającego zadłużenia publicznego jest przedmiotem ożywionej dyskusji wielu środowisk naukowych związanych nie tylko z naukami prawnymi, ale także $\mathrm{z}$ innymi dyscyplinami naukowymi. W związku z powyższym aktualne i potrzebne jest przeanalizowanie aksjologicznych podstaw reguły konstytucyjnego limitu zadłużenia, określonej w art. 216 ust. 5 Konstytucji Rzeczypospolitej Polskiej z 2 kwietnia 
1997 r. ${ }^{1}$ w kontekście wzrostu nie tylko państwowego długu publicznego (PDP), ale również pozostałych konstrukcji finansowoprawnych wyszczególnionych w art. 38 ustawy z 27 sierpnia 2009 r. o finansach publicznych ${ }^{2}$. Utrzymanie stanu zadłużenia publicznego na odpowiednim poziomie ma znaczenie z punktu widzenia zarówno sytuacji wewnętrznej Polski, jak i pozycji państwa na arenie międzynarodowej.

W stanowionym prawie inkorporowane są wartości, które w procesie jego stosowania powinny być odkodowywane i stanowić wyznacznik podejmowanych działań praktycznych. W demokratycznym państwie prawnym istotne jest, aby organy administracji publicznej dostrzegały aksjologiczną podstawę prawa finansów publicznych, tj. pojmowały i rozumiały wartości, jakie wiążą się z tym prawem, a także potrafiły wyodrębniać z grupy różnych wartości te, które będą mogły być uznane za wspólne dla wszystkich i zobiektywizowane, tzn. służące interesowi publicznemu. Wiadomym bowiem jest, że w gradacji wartości oprzeć można się na różnych kryteriach, tzn. właściwych konkretnemu podmiotowi, gałęzi prawa, czy też opartych na innych czynnikach subiektywizujących ich „wiodące” znaczenie. Sztuka zarządzania finansami publicznymi wymaga przede wszystkim skoncentrowania się na wartościach wspólnych i uniwersalnych, a zatem służących ogółowi podmiotów, nie zaś zaspokajaniu partykularnych interesów wąskich grup społecznych. Działanie to implikuje konieczność stosowania właściwych narzędzi prowadzenia gospodarki finansowej, służących efektywnemu wydatkowaniu środków publicznych. W takich bowiem warunkach podejmowane aktywności skutkować będą poprawą jakości zarządzania finansami publicznymi przez organy administracji publicznej.

Aksjologia prawa jest szczególnie istotna w prawie finansów publicznych, ponieważ na etapie zarówno tworzenia tego prawa, jak i jego stosowania wartości (cele) wyznaczają kierunki pożądanego sposobu regulowania i wpływania na zachowanie organów administracji publicznej

$1 \quad$ Konstytucja Rzeczypospolitej Polskiej z 2 kwietnia 1997 r. (Dz.U. Nr 78, poz. 483 ze zm.), dalej: Konstytucja RP, Ustawa zasadnicza.

2 Ustawa z 27 sierpnia 2009 r. o finansach publicznych (tekst jedn. Dz.U. z 2021 r. poz. 305 ze zm.), dalej: u.f.p. 
oraz społeczeństwa. Prawo to u swych podstaw oparte jest bowiem na określonych wartościach i służy ich ochronie, a zatem można uznać, że urzeczywistnia system tych wartości ${ }^{3}$. Cele, o których mowa, stanowiły przedmiot analizy w licznych rozstrzygnięciach Trybunału Konstytucyjnego (dalej: TK), stąd w opracowaniu oparto się na bogatym dorobku orzeczniczym TK, wzbogacając czynione w tym zakresie rozważania o poglądy przedstawicieli doktryny prawa finansowego. Uznano to za niezbędne z punktu widzenia wyników analiz statystycznych związanych z danymi wyszczególnianymi w obwieszczeniach Ministra Finansów wydawanych na podstawie art. 38 u.f.p.

W dobie stanu epidemii wywołanej pandemią COVID-19 nie można było zapominać o potrzebie stałego monitorowania oraz analizowania przyczyn i skutków postępującego zadłużenia publicznego. Stanowi to asumpt do podjęcia badań nad zjawiskiem dynamiki takich kategorii finansowoprawnych, jak PDP, dług Skarbu Państwa oraz zobowiązania z tytułu poręczeń i gwarancji udzielanych przez Skarb Państwa i jednostki sektora finansów publicznych w ostatnich pięciu latach budżetowych. Celem opracowania jest zwrócenie szczególnej uwagi na stan zagrożenia stabilności i bezpieczeństwa sektora finansów publicznych, różnice kwotowe wynikające $\mathrm{z}$ odmiennej metodologii liczenia długu publicznego w Polsce i Unii Europejskiej (UE) i znaczącego wzrostu niewymagalnych zobowiązań z tytułu poręczeń i gwarancji udzielanych przez Skarb Państwa (SP). Zakres merytorycznych rozważań będzie wyznaczony treścią art. 38 u.f.p., zaś punktem odniesienia w badaniach statystycznych będzie rok 2020. W opracowaniu uwzględniono stan prawny obowiązujący na dzień 5 listopada $2021 \mathrm{r}$.

\section{Stabilność finansów publicznych jako wartość chroniona}

Zgodnie z regułą ustanowioną w Konstytucji RP nie wolno zaciągać pożyczek lub udzielać gwarancji i poręczeń finansowych, w następstwie

3 Por. T. Stawecki, P. Winczorek, Wstęp do prawoznawstwa, Warszawa 2000, s. 25. 
których państwowy dług publiczny (PDP) przekroczy 3/5 wartości rocznego produktu krajowego brutto (PKB). W doktrynie prawa finansowego podkreśla się, że jest to bezprecedensowy przykład przeniesienia części postanowień prawa unijnego do Konstytucji RP ${ }^{4}$. Jest to przy tym bezwarunkowe normatywne rozwiązanie prawne, zatem skutkiem przekroczenia konstytucyjnego limitu zadłużenia jest naruszenie przepisu Ustawy zasadniczej, co pociąga za sobą konieczność poszukiwania i dochodzenia odpowiedzialności osób zajmujących najwyższe stanowiska, których zachowania spowodowały przekroczenie tej relacji ${ }^{5}$. Artykuł 216 ust. 5 Konstytucji RP uzupełniono regulacją art. 220 Konstytucji RP, bowiem zwiększenie wydatków lub ograniczenie dochodów planowanych przez Radę Ministrów nie może powodować ustalenia przez Sejm większego deficytu budżetowego niż przewidziany w projekcie ustawy budżetowej. Należy mieć na uwadze, że relacja PDP do PKB jest powszechnie stosowaną na arenie międzynarodowej metodą oceny stanu finansów publicznych danego państwa. Ze względu jednak na poziom rozwoju gospodarczego poszczególnych państw, sytuację polityczną, strukturę PKB itd. nie sposób określić wspólną dla wszystkich państw granicę tego zadłużenia ${ }^{6}$. Przekroczenie określonego pułapu zadłużenia powoduje wzrost kosztów jego obsługi (głównie z tytułu odsetek) oraz oznacza dla państwa duże ryzyko i pogarsza jego gospodarcze perspektywy. Zbyt wysoki poziom długu publicznego determinuje spowolnienie rozwoju państwa, prowadząc do stagnacji, a niekiedy nawet do recesji.

Zgodnie z utrwaloną w orzecznictwie $\mathrm{TK}^{7}$ linią interpretacyjną, ustrojodawca traktuje zachowanie równowagi budżetowej oraz właściwy

4 T. Dębowska-Romanowska, Prawo finansowe. Część konstytucyjna wraz z częściq ogólnq, Warszawa 2010, s. 120 oraz Z. Ofiarski, Komentarz do art. 216 Konstytucji $R P$ [w:] M. Safjan, L. Bosek (red.), Konstytucja RP. Tom II. Komentarz do art. 87243, Warszawa 2016, Legalis (dostęp: 5.11.2016 r.), rozdział F, pkt 1.

5 T. Dębowska-Romanowska, Prawo..., s. 118-119 oraz R. Mroczkowski, Numeryczne reguły wydatkowe jako instrumenty wzmacniajq̨ce stabilność fiskalnq [w:] W. Miemiec, K. Sawicka (red.), Instytucje prawnofinansowe w warunkach kryzysu gospodarczego, Warszawa 2014, s. 323-324.

6 Z. Ofiarski, Komentarz..., rozdział F, pkt 5.

7 Dalej: TK. 
stan finansów publicznych za wartości konstytucyjnie chronione ${ }^{8}$, przez co podkreśla się potrzebę zachowania zdolność państwa do działania i rozwiązywania jego różnorodnych problemów ${ }^{9}$. Dlatego też miarkowanie długu publicznego jest warunkiem zachowania tej konstytucyjnie chronionej wartości ${ }^{10}$. Należy przy tym mieć na względzie, że choć brak równowagi budżetowej nie jest pożądany, to jednak jest w warunkach polskich akceptowalny. Obowiązkiem organów stosujących prawo jest przy tym troska o stabilność i bezpieczeństwo finansów państwa, szczególnie w sytuacjach ekstraordynaryjnych, gdyż stosowane przez państwo środki mające na celu ochronę równowagi finansów publicznych muszą być zgodne z regułami określonymi przez Konstytucję RP. Słusznie w doktrynie podkreśla się, że ratio legis art. 216 ust. 5 Konstytucji RP, tzn. wyrażonego w nim „dopuszczalnego limitu państwowego długu publicznego, jest nie tylko zakaz przekraczania wysokości długu (powstającego w wyniku zaciąganych pożyczek oraz udzielanych gwarancji i poręczeń finansowych), lecz także zapobieganie nadmiernemu zadłużaniu państwa w kolejnych latach. Przyjęte rozwiązanie konstytucyjne powinno zwiększać gospodarczą i międzynarodową wiarygodność państwa”"11.

Zasada wyrażona w art. 216 ust. 5 Konstytucji RP doznaje jednak pewnych ograniczeń, które wynikają z potrzeby poszanowania innych przewidzianych w Konstytucji RP wartości. Zgodnie bowiem z art. 228 ust. 1 Ustawy zasadniczej w sytuacjach szczególnych zagrożeń, jeżeli zwykłe środki konstytucyjne są niewystarczające, może zostać wprowadzony odpowiedni do sytuacji stan nadzwyczajny, tzn. stan wojenny, stan wyjątkowy lub stan klęski żywiołowej. Każdy z ww. stanów prowadzić ma do jak najszybszego przywrócenia stabilnego funkcjonowania pań-

8 Wyrok TK z 12 grudnia 2012 r., K1/12, „Orzecznictwo Trybunału Konstytucyjnego” A 2012, nr 11, poz. 134; wyrok TK z 4 grudnia 2000 r., K 9/00, „Orzecznictwo Trybunału Konstytucyjnego” 2000, nr 8, poz. 294; wyrok TK z 27 lutego 2002 r., K 47/01, „Orzecznictwo Trybunału Konstytucyjnego” - A 2002, nr 1, poz. 6.

9 Orzeczenie TK z 30 listopada 1993 r., K 18/92, „Orzecznictwo Trybunału Konstytucyjnego” 1993, nr 2, poz. 41; wyrok TK z 17 grudnia 1997 r., K 22/96, „Orzecznictwo Trybunału Konstytucyjnego" 1997, nr 5-6, poz. 71.

10 Por. wyrok TK z 4 maja 2004 r., K. 40/2002, „Orzecznictwo Trybunału Konstytucyjnego Zbiór Urzędowy” 2004, nr 5A, poz. 38.

11 Z. Ofiarski, Komentarz..., rozdział F, pkt 3. 
stwa. Istotne jest przy tym to, że zarówno zasady działania organów władzy publicznej, jak i zakres, w jakim mogą zostać ograniczone wolności i prawa człowieka i obywatela w czasie poszczególnych stanów nadzwyczajnych, określa ustawa ${ }^{12}$. Nie jest to zatem obszar dyskrecjonalnych decyzji organów administracji publicznej, a ustawowo określone sytuacje. Do żadnego z ww. stanów nie zalicza się stan epidemii.

Stabilność finansowa państwa jest zatem wartością, która podlega szczególnej ochronie i jest warunkiem wzrostu gospodarczego Polski, dlatego też można uznać, że jest to szczególne dobro chronione służące interesowi publicznemu ${ }^{13}$. W literaturze przedmiotu wskazano, że stabilność finansowa to „taki stan, w którym system finansowy pełni w sposób ciągły i efektywny swoje funkcje, nawet w przypadku wystąpienia zaburzeń”14. Warunkiem istnienia systemu stabilnego jest zatem możliwość samodzielnego powrotu do stanu równowagi bez interwencji z zewnątrz, gdy wystąpią warunki ekstraordynaryjne ${ }^{15}$. Jest to szczególnie ważne w warunkach pandemii COVID-19.

\section{Dynamika wzrostu państwowego długu publicznego i długu Skarbu Państwa w latach 2016-2020}

Szczególnie istotna w prawie finansów publicznych jest zasada jawności, która sprzyja wzrostowi efektywności gospodarowania środkami publicznymi oraz napływowi kapitału zagranicznego (wybierającemu rynki o wysokim stopniu stabilności i jasno sprecyzowanych regułach funkcjo-

12 Z. Ofiarski, Prawo finansowe, Warszawa 2010, s. 63.

13 Por. O. Szczepańska, Podstawowe przesłanki, założenia i struktura sieci bezpieczeństwa finansowego w świetle teorii i doświadczeń międzynarodowych, „Bezpieczny Bank” 2005, nr 1, s. 20.

14 A. Dobrzańska, E. Kosycarz, B. Pietrzak, Stabilność systemu finansowego w gospodarce - rozważania teoretyczne i praktyczne aspekty [w:] A. Alińska, K. Wasiak (red.), Mechanizmy stabilności systemu finansowego, Warszawa 2017, s. 18.

15 Por. tamże, s. 19. 
nowania), a także zwiększa dyscyplinę budżetową ${ }^{16}$. W doktrynie wyróżniono jej ujęcie formalne oraz materialne, przy czym wyrazem pierwszego z tych ujęć są postanowienia art. 38 u.f.p. ${ }^{17}$ Artykuł ten jest istotnie powiązany z regulacją art. 216 ust. 5 Konstytucji RP. Informacje wynikające z realizacji postanowień art. 38 u.f.p. służą bowiem podejmowaniu prewencyjnych działań zapobiegających przekroczeniu czy też nawet zbliżeniu się do limitu zadłużenia określonego w przepisie art. 216 ust. 5 Konstytucji RP. Minister Finansów ogłasza w drodze obwieszczenia, w Dzienniku Urzędowym Rzeczypospolitej Polskiej „Monitor Polski”, kwotę i relację do PKB: PDP, długu Skarbu Państwa (dług SP) oraz niewymagalnych zobowiązań z tytułu poręczeń i gwarancji udzielonych przez Skarb Państwa (PiG SP). Ponadto Minister Finansów podaje również kwotę niewymagalnych zobowiązań z tytułu poręczeń i gwarancji udzielonych przez jednostki sektora finansów publicznych (PiG JSFP). Dane te dotyczą stanu na koniec roku budżetowego i są ogłaszane w terminie do 31 maja roku następnego. Można uznać, że zasady utrwalone w treści art. 38 u.f.p. sprzyjają stabilności w finansach publicznych poprzez utrzymanie zaufania społecznego do działań podejmowanych w sferze finansów publicznych przez uprawnione organy. Dzieję się tak poprzez możliwość kontrolowania i oceny sposobu gospodarowania powierzonymi środkami publicznymi.

W poniższych tabelach zestawiono dane dotyczące lat 2016-2020 w celu zobrazowania wpływu stanu epidemii na wzrost kwot, o których mowa w art. 38 u.f.p. W poczuciu troski o zachowanie właściwego stanu finansów publicznych i poszanowania wartości konstytucyjnych, którym służyć powinny przedmiotowe postanowienia prawne, należy to uznać za potrzebne.

\footnotetext{
${ }^{16}$ W. Misiąg, A. Niedzielski, Jawność i przejrzystość finansów publicznych w Polsce w świetle standardów Międzynarodowego Funduszu Walutowego, „Zeszyty Instytutu Badań nad Gospodarką Rynkową - IbnGR” 2001, nr 29, s. 9.

${ }^{17}$ Por. E. Malinowska-Misiąg, komentarz do art. 33 u.f.p. [w:] W. Misiąg (red.), Ustawa o finansach publicznych. Ustawa o odpowiedzialności za naruszenie dyscypliny finansów publicznych. Komentarz, Wyd. 3, Warszawa 2019, Legalis (dostęp: 5.11.2021), rozdział I.B, pkt 1.
} 
Tabela 1. Kwota i relacja do PKB państwowego długu publicznego i długu Skarbu Państwa w latach 2016-2020.

\begin{tabular}{|c|c|c|c|c|}
\hline Rok & PDP (mln PLN) & PDP/PKB (w \%) & dług SP (mln PLN) & dług SP/PKB (w \%) \\
\hline 2016 & 965198 & 52,1 & 928666,00 & 50,20 \\
\hline 2017 & 961819 & 48,5 & 928473,00 & 46,80 \\
\hline 2018 & 984318 & 46,5 & 954269,00 & 45,10 \\
\hline 2019 & 990941 & 43,6 & 973338,00 & 42,80 \\
\hline 2020 & 1111798 & 47,8 & 1097480,00 & 47,20 \\
\hline
\end{tabular}

Źródło: opracowanie własne na podstawie: obwieszczenie Ministra Rozwoju i Finansów z 25 maja 2017 r. w sprawie ogłoszenia kwot, o których mowa w art. 38 i art. 38a ustawy o finansach publicznych (M.P. z 2017 r. poz. 508); obwieszczenie Ministra Finansów z 21 maja 2018 r. w sprawie ogłoszenia kwot, o których mowa w art. 38 i art. 38a ustawy o finansach publicznych (M.P. z 2018 r. poz. 511); obwieszczenie Ministra Finansów z 27 maja 2019 r. w sprawie ogłoszenia kwot, o których mowa w art. 38 i art. 38a ustawy o finansach publicznych (M.P. z 2019 r. poz. 468), obwieszczenie Ministra Finansów z 22 maja 2020 r. w sprawie ogłoszenia kwot, o których mowa w art. 38 i art. 38a ustawy o finansach publicznych (M.P. z 2020 r. poz. 456.), obwieszczenie Ministra Finansów, Funduszy i Polityki Regionalnej z 24 maja 2021 r. w sprawie ogłoszenia kwot, o których mowa w art. 38 i art. 38a ustawy o finansach publicznych (M.P. z 2021 r. poz. 492).

Uwzględniając dane zaprezentowane $\mathrm{w}$ tabeli 1, trzeba wskazać, że na wzrost PDP składają się nie tylko deficyty budżetowe na poziomie centralnym oraz budżetów lokalnych danego roku, ale „także »nie wykupione« obligacje i inne papiery oraz niespłacone kredyty na pokrycie defi-

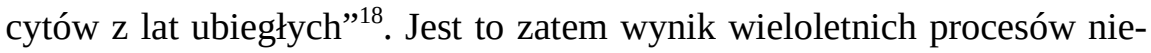
zrównoważonej gospodarki finansowej (powtarzających się i niespłaconych deficytów).

PDP w 2020 r. w porównaniu do roku poprzedniego zwiększył się o ponad 120 mld PLN, co skutkuje ok. 4\% wzrostem relacji PDP do PKB, przy czym z zestawienia kwot PDP i długu SP jednoznacznie wynika, że zadłużenie publiczne $\mathrm{w}$ dominującym zakresie dotyczy podsektora

18 Wyrok TK z 4 maja 2004 r., K. 40/2002, „Orzecznictwo Trybunału Konstytucyjnego. Zbiór Urzędowy” 2004, nr 5A, poz. 38. 
rządowego (blisko 99\% PDP), nie zaś samorządowego. Wobec zaplanowanego w 2021 r. deficytu budżetu państwa na kwotę ponad 40,5 mld $\mathrm{PLN}^{19}$ trudno się spodziewać istotnej poprawy sytuacji finansowej w sektorze publicznym czy też zahamowania dynamiki wzrostu PDP i długu SP.

Tabela 2. Kwota i relacja do PKB długu sektora instytucji rządowych i samorządowych oraz państwowego długu publicznego w latach 2016-2020.

\begin{tabular}{|c|c|c|c|c|}
\hline Rok & EDP (mln PLN) & EDP/PKB (w \%) & PDP (mln PLN) & PDP/PKB (w \%) \\
\hline 2016 & 1006287 & 54,30 & 965198 & 52,1 \\
\hline 2017 & 1003399 & 50,60 & 961819 & 48,5 \\
\hline 2018 & 1033641 & 48,80 & 984318 & 46,5 \\
\hline 2019 & 1045122 & 46,10 & 990941 & 43,6 \\
\hline 2020 & 1335569 & 57,60 & 1111798 & 47,8 \\
\hline
\end{tabular}

Źródło: opracowanie własne na podstawie: obwieszczenie Ministra Rozwoju i Finansów z 25 maja 2017 r. w sprawie ogłoszenia kwot, o których mowa w art. 38 i art. 38a ustawy o finansach publicznych (M.P. z 2017 r. poz. 508), obwieszczenie Ministra Finansów z 21 maja 2018 r. w sprawie ogłoszenia kwot, o których mowa w art. 38 i art. 38a ustawy o finansach publicznych (M.P. z 2018 r. poz. 511), obwieszczenie Ministra Finansów z 27 maja 2019 r. w sprawie ogłoszenia kwot, o których mowa w art. 38 i art. 38a ustawy o finansach publicznych (M.P. z 2019 r. poz. 468), obwieszczenie Ministra Finansów z 22 maja 2020 r. w sprawie ogłoszenia kwot, o których mowa w art. 38 i art. 38a ustawy o finansach publicznych (M.P. z 2020 r. poz. 456.), obwieszczenie Ministra Finansów, Funduszy i Polityki Regionalnej z 24 maja 2021 r. w sprawie ogłoszenia kwot, o których mowa w art. 38 i art. 38a ustawy o finansach publicznych (M.P. z 2021 r. poz. 492) oraz dane opublikowane na stronie: www.gov.pl/web/finanse/zadluzenie-sektora-finansowpublicznych (dostęp: 5.11.2021 r.).

Należy podkreślić, że kwoty z tabeli 1 wyliczono na podstawie metodyki polskiej. W Polsce obowiązują jednak dwie metody liczenia zadłu-

19 Ustawa budżetowa na rok 2021 z 20 stycznia 2021 r. (Dz.U. z 2021 r. poz. 190 ze zm.), przy czym należy wskazać, że w wersji pierwotnej tej ustawy deficyt ustalono w kwocie 82,3 mld PLN, a dopiero ustawą z 1 października 2021 r. o zmianie ustawy budżetowej na rok 2021 (Dz.U. 2021 poz. 1900) obniżono tę kwotę do 40,5 mld PLN. 
żenia publicznego: krajowa oraz właściwa prawu wspólnotowemu ${ }^{20}$, co nie sprzyja przejrzystości finansów publicznych i jednocześnie utrudnia porównywanie danych. Różnice między tymi metodami mają istotny wymiar kwotowy, co zaprezentowano na wykresie 1. Szczególnie niepokojące są dane dotyczące 2020 r., w którym dług sektora instytucji rządowych i samorządowych (EDP) wzrósł o 290 mld PLN (w porównaniu do 2019 r.), co wiązało się z jednoczesnym wzrostem relacji tego długu do PKB o $11,5 \%$, czyli do $57,6 \%$. Warto zasygnalizować przy tym, że zgodnie z informacjami opublikowanymi przez Ministerstwo Finansów ${ }^{21}$ kwota długu EDP w drugim kwartale 2021 r. wyniosła 1401 619,6 mln PLN, zaś PDP 1152 190,6 mln PLN, a zatem zadłużenie publiczne niezależnie od przyjętej metodyki jego liczenia wzrasta również w 2021 r.

Wśród istotnych różnic metodologicznych liczenia długu publicznego należy wskazać nieujmowanie w PDP funduszy utworzonych w ramach Banku Gospodarstwa Krajowego (BGK), a jedynie zobowiązań jednostek sektora finansów publicznych wymienionych w art. 9 u.f.p. Ponadto w PDP ujmuje się wyłącznie zobowiązania wymagalne, zaś dług potencjalny nie jest brany pod uwagę. Tymczasem w metodologii unijnej istotne są nie tylko funkcje wykonywane przez dane jednostki, ale także sposób ich finansowania, dlatego dług EDP obejmuje różne jednostki instytucjonalne, w tym jednostki sektora instytucji rządowych i samorządowych, inne instytucje (np. instytucję typu przedsiębiorstwo), instytucje niekomercyjne uznane za samodzielne jednostki posiadające osobowość prawną, które są producentami nierynkowymi i są kontrolowane przez jednostki sektora instytucji rządowych i samorządowych, a także autonomiczne fundusze emerytalno-rentowe, w których istnieje prawny obowiązek płacenia składek, a sektor instytucji rządowych i samorządowych zarządza funduszami w zakresie rozliczania i zatwierdzania składek

20 Szerzej: M. Jóźwiak, Pojęcie długu. Statystyka długu publicznego. Metodologia ustalania zadłużenia [w:] P. Walczak (red.), Zadłużenie jednostek samorzq̨du terytorialnego. Wyzwania w obliczu nowej perspektywy finansowej UE, Warszawa 2014, s. 5-7.

21 Ministerstwo Finansów, Zadłużenie Sektora Finansów Publicznych II kw./2021, Biuletyn kwartalny, Warszawa, 10.09.2021 r., https://www.gov.pl/web/finanse/zadluzeniesektora-finansow-publicznych (dostęp: 5.11.2021 r.), s. 1. 
i świadczeń ${ }^{22}$. Różnice metodologiczne dotyczące wskazanych w tabeli 2 ujęć zadłużenia publicznego wskazują na to, że w 2020 r. dług EDP był wyższy od PDP o ok. 224 mld PLN.

Wykres 1. Zestawienie dynamiki kwot długu EDP i PDP w latach 2016-2020.

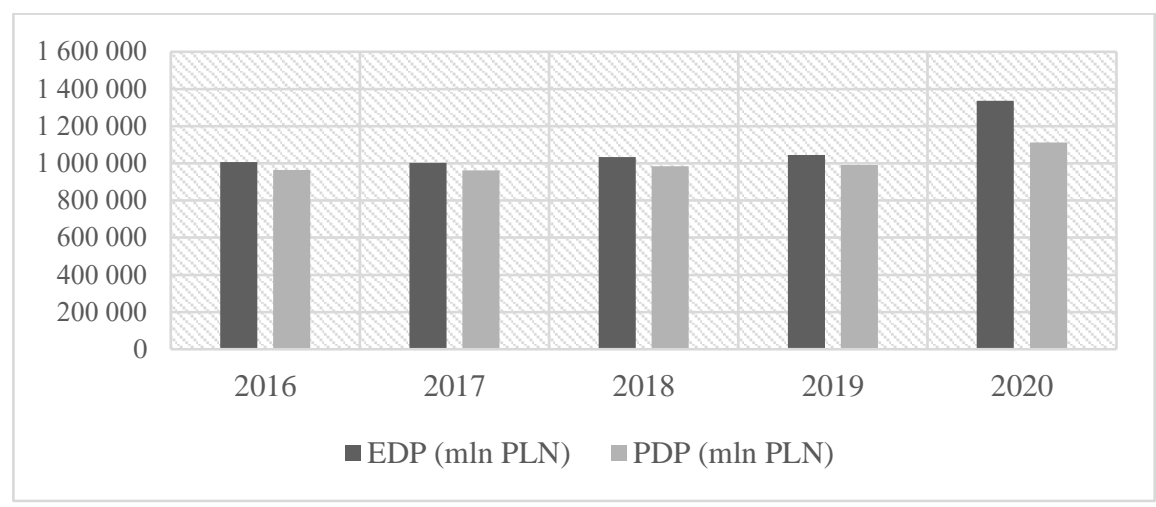

Źródło: opracowanie własne na podstawie źródeł wskazanych w tabeli 2.

\section{Dynamika wzrostu niewymagalnych zobowiązań z tytułu poręczeń i gwarancji udzielonych przez Skarb Państwa i jednostki sektora finansów publicznych w latach 2016-2020}

Rada Ministrów przedstawia corocznie Sejmowi w terminie właściwym do przedstawienia sprawozdania z wykonania budżetu państwa za dany rok informację o poręczeniach i gwarancjach udzielonych przez SP, niektóre osoby prawne oraz BGK w ramach programów rządowych oraz Funduszu Gwarancji Płynnościowych. Jest to zatem kolejny przejaw respektowania zasady jawności w finansach publicznych i prawa obywateli do informacji o stanie zobowiązań sektora finansów publicznych. Przyświeca temu potrzeba ogólnie pojętej troski o wartość, jaką jest stabilność

22 Rozporządzenie Parlamentu Europejskiego i Rady (UE) nr 549/2013 z dnia 31 maja 2013 r. w sprawie europejskiego systemu rachunków narodowych i regionalnych w Unii Europejskiej (Dz. Urz. UE L 174 z 26 czerwca 2013 r.). 
finansów publicznych. Uzasadnienie aksjologiczne regulacji art. 46 ustawy z 8 maja 1997 r. o poręczeniach i gwarancjach udzielanych przez Skarb Państwa oraz niektóre osoby prawne ${ }^{23}$ należy również oprzeć na dążeniu do kontroli stanu zagrożenia bezpieczeństwa finansów publicznych. Zagrożenie to związane może być również z zadłużeniem potencjalnym, które dotyczy niewymagalnych zobowiązać łączonych z udzielanymi w sektorze finansów publicznych poręczeniami i gwarancjami. Należy mieć na względzie, że przyczyny niestabilności finansowej mogą mieć nie tylko podłoże egzogeniczne, ale także endogeniczne.

Artykuł 38 u.f.p. stanowi o obowiązku corocznego podawania do publicznej wiadomości danych dotyczących zobowiązań z tytułu udzielanych poręczeń i gwarancji SP oraz jednostek sektora finansów publicznych, które należy traktować jako potencjalne zadłużenie, tzn. zobowiązania wynikające $\mathrm{z}$ aktualnych aktów prawnych bądź zawartych umów, ale których wysokość jest trudna do określenia, czy też których zapadalność wiąże się z wystąpieniem konkretnego zdarzenia niepewnego (zdarzenie to może nie nastąpić) ${ }^{24}$. Ustawodawca słusznie zatem, kierując się troską o zapewnienie stabilności i bezpieczeństwa w sektorze finansów publicznych oraz respektując aksjologiczne podłoże wprowadzanych rozwiązań, zobligował Ministra Finansów do corocznego ujawniania kwot analizowanych zobowiązań niewymagalnych. Potwierdzeniem powyższego jest budzący uzasadniony niepokój blisko dwukrotny wzrost ww. zobowiązań w 2020 r. (w porównaniu do 2019 r.). W analizowanym okresie w kwocie PiG JSFP dominowały zobowiązania z tytułu poręczeń i gwarancji udzielanych przez SP (od ok. 97\% w latach 2016-2019) do blisko 99\% w 2020 r. Z „Informacji o poręczeniach i gwarancjach udzielonych w 2020 roku przez Skarb Państwa, niektóre osoby prawne oraz Bank Gospodarstwa Krajowego" 25 wynika, że wzrost ten należy wiązać bezpo-

23 Ustawa z 8 maja 1997 r. o poręczeniach i gwarancjach udzielanych przez Skarb Państwa oraz niektóre osoby prawne (tekst jedn. Dz.U. z 2021 r. poz. 442 ze zm.).

24 K. Marchewka-Bartkowiak, Zarzq̨dzanie długiem publicznym, Warszawa 2008, s. 187.

25 Informacja o poręczeniach i gwarancjach udzielonych w 2020 roku przez Skarb Państwa, niektóre osoby prawne oraz Bank Gospodarstwa Krajowego, Warszawa 2021, https://www.gov.pl/web/finanse/informacje-roczne-poreczenia-i-gwarancje (dostęp: 5.11.2021 r.), s. 2, dalej: informacja o poręczeniach i gwarancjach. 
średnio ze stanem epidemii, bowiem gwarancjami SP zostały objęte zobowiązania BGK wynikające z obligacji wyemitowanych na rzecz Funduszu Przeciwdziałania COVID-19²6 (na łączną kwotę ok. 116,93 mld PLN), a także zobowiązania Polskiego Funduszu Rozwoju S.A. ${ }^{27}$ wynikające z obligacji wyemitowanych na realizację kilku programów rządowych ${ }^{28}$ (na łączną kwotę ok. 71,17 mld PLN). Zachowując obiektywizm, należy przy tym podkreślić, że zobowiązania związane z tymi gwarancjami są obarczone niskim ryzykiem ich spłaty przez gwaranta (Skarb Państwa) ${ }^{29}$.

Tabela 3. Kwota niewymagalnych zobowiązań z tytułu udzielonych poręczeń i gwarancji przez jednostki sektora finansów publicznych oraz kwota i relacja do PKB niewymagalnych zobowiązań z tytułu poręczeń i gwarancji Skarbu Państwa w latach 2016-2020.

\begin{tabular}{|c|c|c|c|}
\hline Rok & PiG JSFP (mln PLN) & PiG SP (mln PLN) & PiG SP/PKB (w \%) \\
\hline 2016 & 128210,00 & 124514,00 & 6,70 \\
\hline 2017 & 120380,00 & 116878,50 & 5,90 \\
\hline 2018 & 112378,00 & 108798,70 & 5,10 \\
\hline 2019 & 114869,00 & 111371,30 & 4,90 \\
\hline 2020 & 306846,00 & 302875,00 & 13,00 \\
\hline
\end{tabular}

Źródło: opracowanie własne na podstawie: obwieszczenie Ministra Rozwoju i Finansów z 25 maja 2017 r. w sprawie ogłoszenia kwot, o których mowa w art. 38 i art. 38a ustawy o finansach publicznych (M.P. z 2017 r. poz. 508), obwieszczenie Ministra Finansów z 21 maja 2018 r. w sprawie ogłoszenia kwot, o których mowa w art. 38 i art. 38a ustawy o finansach publicznych (M.P. z 2018 r. poz. 511), obwieszczenie Ministra Finansów z 27 maja 2019 r. w sprawie ogłoszenia kwot, o których

26 Na podstawie art. 67 ust. 4 ustawy z 31 marca 2020 r. o zmianie ustawy o szczególnych rozwiązaniach związanych z zapobieganiem, przeciwdziałaniem i zwalczaniem COVID-19, innych chorób zakaźnych oraz wywołanych nimi sytuacji kryzysowych oraz niektórych innych ustaw (Dz.U. z 2020 r. poz. 568, ze zm.).

27 Na podstawie art. 21aa ust. 2 ustawy z 4 lipca 2019 r. o systemie instytucji rozwoju (Dz.U. z 2020 r. poz. 2011 ze zm.).

28 Były to programy rządowe: „Tarcza finansowa Polskiego Funduszu Rozwoju dla małych i średnich firm”, „Tarcza finansowa Polskiego Funduszu Rozwoju dla dużych firm”, „Tarcza finansowa 2.0 Polskiego Funduszu Rozwoju dla mikro, małych i średnich firm” oraz „Programu wsparcia Polskich Linii Lotniczych LOT S.A.”

Por. Informacja..., s. 12. 
mowa w art. 38 i art. 38a ustawy o finansach publicznych (M.P. z 2019 r. poz. 468), obwieszczenie Ministra Finansów z 22 maja 2020 r. w sprawie ogłoszenia kwot, o których mowa w art. 38 i art. 38a ustawy o finansach publicznych (M.P. z 2020 r. poz. 456.), obwieszczenie Ministra Finansów, Funduszy i Polityki Regionalnej z 24 maja 2021 r. w sprawie ogłoszenia kwot, o których mowa w art. 38 i art. 38a ustawy o finansach publicznych (M.P. z 2021 r. poz. 492).

\section{Podsumowanie}

W Konstytucji RP przewidziano środki służące kontroli prowadzenia zrównoważonej gospodarki finansowej państwa. Orzecznictwo TK jest zgodne w zakresie potrzeby zachowania właściwego stanu finansów publicznych, które powinny być zarówno stabilne, jak i bezpieczne. Służą temu konstytucyjne gwarancje dotyczące zakazu przekraczania określonej relacji zadłużenia publicznego do PKB oraz podejmowanie działań oszczędnościowych, adekwatnych do sytuacji ${ }^{30}$. Wyrazem troski ustawowej o stan finansów publicznych są liczne uregulowania prawne obligujące do publikowania informacji istotnych z punktu widzenia zadłużenia publicznego.

Można jednoznacznie uznać, że w procesie zarówno stanowienia, jak i stosowania prawa istotne znaczenie ma podłoże aksjologiczne wprowadzanych rozwiązań prawnych. Troska o dobro wspólne, poszanowanie wolności człowieka i obywatela oraz jego godności, które są wartościami powszechnymi, ma istotne znaczenie $\mathrm{w}$ procesie interpretowania prawa finansowego. Dzięki temu możliwe jest podporządkowywanie zachowania podmiotów określonym ogólnym regułom postępowania w dążeniu do osiągnięcia zawartych $\mathrm{w}$ prawie wartości pożądanych społecznie ${ }^{31}$. Uszczegóławiając powyższe, można wyróżnić wartości właściwe stricte prawu finansowemu, takie jak stabilność finansów publicznych, bezpieczeństwo sektora finansów publicznych, równowaga budżetowa itd. Odkodowywanie wartości właściwych prawu finansowemu z obowiązujących przepisów nabiera na znaczeniu zwłaszcza w aktualnej sytuacji gospodarczej Polski. Porównanie stosowanej w Polsce metodologii liczenia

30 Wyrok TK z 12 grudnia 2012 r., K 1/12, „Orzecznictwo Trybunału Konstytucyjnego” - A 2012, nr 11, poz. 134.

31 R. Tokarczyk, Wstęp [w:] L.L. Fuller, Moralność prawa, Warszawa 2004, s. XII. 
zadłużenia publicznego z metodologią unijną świadczy o możliwości różnego ukazywania stanu finansów publicznych. Implikuje to potrzebę stałego kontrolowania i weryfikowania danych publikowanych przez właściwe organy. Istota pełnego i nieskrępowanego dostępu do tych informacji stanowi o potrzebie ścisłego respektowania zasady jawności w finansach publicznych. W informacji o poręczeniach i gwarancjach podkreślono, że kontrola narastania zobowiązań z tytułu udzielanych poręczeń i gwarancji ma szczególne znaczenie z punktu widzenia bezpieczeństwa finansów publicznych. Omawiana problematyka powinna podlegać stałej kontroli przede wszystkim z uwagi na wysoki poziom potencjalnych, niewymagalnych zobowiązań SP z tytułu udzielonych poręczeń i gwarancji. Doświadczenia związane z pandemią COVID-19 doprowadziły do jej uznania za jeden $\mathrm{z}$ podstawowych elementów warunkujących realizację rządowego programu realizowanego przez BGK, tzn. Programu Wspierania Przedsiębiorczości.

W okresie pandemii COVID-19 zaobserwować można znaczący wzrost kwot PDP, długu SP, niewymagalnych zobowiązań z tytułu udzielonych poręczeń i gwarancji SP (i ich relacji do PKB), a także wzrost kwoty długu EDP. Rodzi to uzasadnioną potrzebę dalszego skrupulatnego monitorowania stanu finansów publicznych, racjonalnego wydatkowania środków publicznych i efektywnego ich gromadzenia. Przy podejmowaniu określonych działań o znaczeniu finansowym szczególnie istotny staje się postulat prowadzenia wyważonej polityki finansowej, tzn. przemyślanej w zakresie pożądanych skutków (długo- i krótkoterminowych konsekwencji) i możliwych do wystąpienia zaburzeń (ryzyka niepowodzenia osiągnięcia założonych celów). Kierunki prowadzonej polityki finansowej powinny być przy tym adekwatne do aktualnej sytuacji gospodarczej i społecznej. Pandemia COVID-19 wykazała także potrzebę kontynuowania dyskusji nad zasadnością stosowania odmiennej metodologii liczenia zadłużenia publicznego $\mathrm{w}$ prawie polskim i w unijnym porządku prawnym. Należy rozważyć, czy sprzyja to przejrzystości finansów publicznych, tzn. uzyskaniu pełnego, rzetelnego i zrozumiałego obrazu sytuacji finansowej państwa i poszczególnych elementów sektora publicznego. Jasne sprecyzowanie zasad gospodarowania środkami publicznymi jest 
potrzebne i z pewnością leży u podstaw aksjologicznych prawa finansów publicznych. Tylko bowiem w takich warunkach istnieje możliwość faktycznego poznania i zrozumienie procesów składających się na finanse publiczne.

\section{Bibliografia:}

Dębowska-Romanowska T., Prawo finansowe. Część konstytucyjna wraz z częściq ogólnq, C.H. Beck, Warszawa 2010.

Dobrzańska A., Kosycarz E., Pietrzak B., Stabilność systemu finansowego w gospodarce - rozważania teoretyczne i praktyczne aspekty [w:] A. Alińska, K. Wasiak (red.), Mechanizmy stabilności systemu finansowego, C.H. Beck, Warszawa 2017.

Jóźwiak M., Pojęcie długu. Statystyka długu publicznego. Metodologia ustalania zadłużenia, [w:] P. Walczak (red.), Zadłużenie jednostek samorzqdu terytorialnego. Wyzwania w obliczu nowej perspektywy finansowej UE, C.H. Beck, Warszawa 2014.

Malinowska-Misiąg E., Komentarz do art. 33 u.f.p. [w:] W. Misiąg (red.), Ustawa o finansach publicznych. Ustawa o odpowiedzialności za naruszenie dyscypliny finansów publicznych. Komentarz, Wyd. 3, C.H. Beck, Warszawa 2019.

Marchewka-Bartkowiak K., Zarzq̨dzanie długiem publicznym, PWN, Warszawa 2008.

Misiąg W., Niedzielski A., Jawność i przejrzystość finansów publicznych w Polsce w świetle standardów Międzynarodowego Funduszu Walutowego, „Zeszyty Instytutu Badań nad Gospodarką Rynkową - IbnGR” 2001, nr 29, s. 1-34.

Mroczkowski R., Numeryczne reguły wydatkowe jako instrumenty wzmacniajq̨e stabilność fiskalnq [w:] W. Miemiec, K. Sawicka (red.), Instytucje prawnofinansowe $w$ warunkach kryzysu gospodarczego, Wolters Kluwer, Warszawa 2014.

Ofiarski Z., Komentarz do art. 216 Konstytucji RP [w:] M. Safjan, L. Bosek (red.), Konstytucja RP. Tom II. Komentarz do art. 87-243, C.H. Beck, Warszawa 2016.

Ofiarski Z., Prawo finansowe, C.H. Beck, Warszawa 2010.

Stawecki T., Winczorek P., Wstęp do prawoznawstwa, C.H. Beck, Warszawa 2000.

Tokarczyk R., Wstęp [w:] Fuller L.L., Moralność prawa, ABC, Warszawa 2004. 